\section{Temperature and Storage Time Affect Quality of Yellow Passion Fruit}

\author{
Harvey E. Arjona ${ }^{1}$, Frank B. Matta, and James O. Garner, Jr. \\ Department of Horticulture, P.O. Drawer T, Mississippi State \\ University, Mississippi State, MS 39762
}

Additional index words. postharvest, sugars, fruit characteristics, Passiflora edulis f. Flavicarpa Deg.

Abstract. Vine-ripened yellow passion fruit (Passiflora edulis f. flavicarpa Deg.) packed and shipped from Homestead, Fla., were stored for 15, 30, or 45 days at 5, 10, or 15C. Fruit analyzed immediately on arrival had the best external appearance and highest fruit weight. Fruit weight loss increased with storage time at all temperatures and the response was linear. Fruit external appearance deteriorated rapidly at 5 and 15C. Pulp percentage at $5 \mathrm{C}$ increased linearly with storage duration and did not change at $10 \mathrm{C}$. Pulp percentage at $15 \mathrm{C}$ changed quadratically with storage time, increasing up to 30 days and then decreasing by 45 days. Soluble solids concentration did not change at 5 or $10 \mathrm{C}$, but decreased linearly at $15 \mathrm{C}$. Sucrose content decreased quadratically at $5 \mathrm{C}$, linearly at $15 \mathrm{C}$, but increased linearly at $10 \mathrm{C}$. Fructose and glucose content decreased quadratically with storage time at $15 \mathrm{C}$. Glucose content increased linearly at 5 and $10 \mathrm{C}$ and fructose content did not change at these temperatures.
Produce sensitive to chilling injury $(\mathrm{CI})$ requires storage temperatures above $12 \mathrm{C}$ (Wills et al., 1982). Passion fruit is a tropical climacteric fruit (Biale, 1975; Wills, et al., 1982) subject to chilling injury when stored below 6.5C (Pruthi, 1963). Recommended storage temperatures are 3 to $5 \mathrm{C}$ (Wills et al., 1982), 7 to 10C (McGregor, 1987), and 5 to 7C (Pruthi, 1963). Yellow passion fruit stored longer than 7 to 10 days under ambient conditions is susceptible to shrivel, pulp fermentation, and fungal attack (Pruthi, 1963). However, $80 \%$ of the fruit was judged to be marketable after storage in plastic bags for 14 days at 23C (Salazar and Torres, 1977).

We discuss the effect of temperature and fruit.

Vine-ripened yellow passion fruit, packed in commercial cardboard boxes with 36 individual cell packs and shipped over night via express courier from Homestead, Fla., were randomly grouped in open plastic trays and subjected to one of nine treatments, i.e., storage for 15,30 , or 45 days at 5,10 , or $15 \mathrm{C}$ and $85 \%$ relative humidity $(\mathrm{RH})$. The respective vapor pressure differences were $\approx 140,180$, and $260 \mathrm{~Pa}$, respectively. Each experimental unit consisted of three fruit per treatment and treatments were replicated four times. The experiment was conducted three times using shipping dates as a blocking factor (Petersen, 1985; Steel and Torrie, 1980). Treatments were arranged in a split-plot de-

Received for publication 17 June 1991. Accepted for publication 4 Mar. 1992. Mississippi Agricultural and Forestry Experiment Station Article no. J-7790. The cost of publishing this paper was defrayed in part by the payment of page charges. Under postal regulations. this paper therefore must be hereby marked advertisement solely to indicate this fact.

'Associate Professor, Faculted de Agronomía, Universidad Nacionál de Colombia, Bogota, Columbia. storage time on quality of yellow passion sign with temperature of storage rooms as whole-plots and three storage periods as subplots. Fruit were received at monthly intervals starting in Aug. 1988.

Data analysis based on three fruit per treatment and four replications were taken for the following characteristics: external appearance; fresh fruit weight; percentage of pulp; soluble solids concentration (SSC); and fructose, glucose, and sucrose concentrations. For sugar analysis, one sample per replication (three fruit per replicate) was tested in each experiment. Control fruit were analyzed immediately on arrival. Analysis of variance was performed on all variables and linear and quadratic contrasts were determined for the response of the variables to days in storage.

External fruit appearance was visually determined and expressed as percentage of fruit surface shrivelled. Pulp percentage was ex- pressed as (pulp weight $\div$ by total fruit weight $) \times 100$. We measured SSC with a Bausch and Lomb optical refractometer and expressed in ${ }^{\circ}$ Brix. Fructose, glucose, and sucrose concentration of the juice was determined by means of high-performance liquid chromatography (HPLC) using a carbohydrate analysis column (part number 84038) from Water Associates (Milford, Mass.) as previously described by Arjona et al. (1991).

Fruit external appearance declined linearly with storage time at each storage temperature (Table 1). However, shrivelling was less at 10C. CI, as previously reported for purple passion fruit (Pruthi, 1963), at 5C and water loss at $15 \mathrm{C}$ may have contributed to the higher rates of fruit deterioration at these temperatures. Storage at 10C was recommended for passion fruit by McGregor (1987).

Fruit weight loss percentage consistently increased with storage time at all temperatures and the response was linear. The largest and about equal loss occurred at 10 and $15 \mathrm{C}$ during 45 days of storage. Fruit weight loss percentages in this experiment were similar to those reported by Pruthi (1963) in which weight loss of purple passion fruit increased with increasing temperatures and storage durations.

SSC of fruit stored at 5C did not differ from the control and was not affected by storage time (Table 1). Fruit stored at 10C had a lower SSC than the control, but storage had no effect. Fruit stored at $15 \mathrm{C}$ showed a linear decrease in SSC with storage time. SSC included reducing and nonreducing sugars, organic acids, and other soluble metabolites (Salisbury and Ross, 1985). A greater reduction in SSC would be expected at $15 \mathrm{C}$ because of the higher respiration rate.

Pulp percentage increased linearly with storage time at $5 \mathrm{C}$, did not change at $10 \mathrm{C}$, and changed quadratically at $15 \mathrm{C}$ with storage time (Table 1). Pruthi and Lal (1955) reported the yield of pulp from purple passion fruit to vary from $46 \%$ to $54 \%$. Pulp
Table 1. External appearance percentage, fruit weight loss, soluble solids content (SSC), and fruit pulp percentage of yellow passion fruit as influenced by storage duration at 5,10 , and $15 \mathrm{C}$.

\begin{tabular}{|c|c|c|c|c|c|}
\hline \multicolumn{2}{|c|}{ Storage condition } & \multirow[b]{2}{*}{$\begin{array}{c}\text { External } \\
\text { appearance }\end{array}$} & \multirow{2}{*}{$\begin{array}{c}\text { Fruit } \\
\text { wt loss } \\
(\%)\end{array}$} & \multirow[b]{2}{*}{$\begin{array}{c}\text { SSC } \\
\text { ( }{ }^{\circ} \text { Brix) }\end{array}$} & \multirow[b]{2}{*}{$\begin{array}{c}\text { Fruit pulp } \\
(\%)\end{array}$} \\
\hline $\begin{array}{c}\text { Temp } \\
\left({ }^{\circ} \mathrm{C}\right) \\
\end{array}$ & $\begin{array}{c}\text { Duration } \\
\text { (days) }\end{array}$ & & & & \\
\hline \multicolumn{2}{|l|}{ Controly } & 12 & -- & 15.3 & 44.9 \\
\hline \multirow[t]{3}{*}{5} & 15 & 84 & 18 & 14.5 & 55.9 \\
\hline & 30 & 86 & 39 & 15.7 & 63.9 \\
\hline & 45 & 93 & 48 & 15.8 & 67.4 \\
\hline \multicolumn{2}{|c|}{ Significance $x$} & $L^{* y}$ & $\mathbf{L}^{*}$ & NS & $\mathrm{L}^{*}$ \\
\hline \multirow[t]{3}{*}{10} & 15 & 40 & 16 & 13.0 & 50.6 \\
\hline & 30 & 65 & 26 & 13.0 & 50.8 \\
\hline & 45 & 65 & 65 & 13.0 & 51.4 \\
\hline \multicolumn{2}{|c|}{ Significance } & $\mathrm{L}^{*}$ & $\mathbf{L}^{*}$ & NS & NS \\
\hline \multirow[t]{3}{*}{15} & 15 & 50 & 21 & 12.5 & 51.7 \\
\hline & 30 & 80 & 37 & 10.4 & 56.4 \\
\hline & 45 & 82 & 62 & 4.6 & 50.9 \\
\hline \multicolumn{2}{|c|}{ Significance $^{x}$} & $L^{*}$ & $\mathrm{~L}^{*}$ & $\mathrm{~L}^{*}$ & $\mathrm{Q}^{*}$ \\
\hline
\end{tabular}

${ }^{2}$ Expressed as percentage of surface shrivelled. yFruit analyzed immediately upon arrival.

$\mathbf{x}_{\mathrm{L}}=$ linear, $\mathbf{Q}=$ quadratic.

NS, *Nonsignificant or significant at $P=0.05$. 
Table 2. Sugar content of yellow passion fruit as influenced by storage duration at 5, 10, and $15 \mathrm{C}$.

\begin{tabular}{lcccc}
\hline \hline \multicolumn{2}{c}{ Storage condition } & & & \\
$\begin{array}{l}\text { Temp } \\
\left({ }^{\circ} \mathrm{C}\right)\end{array}$ & $\begin{array}{c}\text { Duration } \\
\text { (days) }\end{array}$ & Sucrose & Fructose & Glucose \\
\hline & & & $g \cdot 100 \mathrm{ml}^{-1}$ & \\
Controlz $^{\mathbf{z}}$ & & 3.1 & 4.7 & 4.9 \\
5 & 15 & 3.0 & 4.5 & 4.2 \\
& 30 & 2.0 & 5.1 & 5.9 \\
Significance & 45 & $\mathrm{~L}^{*} \mathrm{Q}^{*}$ & 5.5 & $\mathrm{~L}^{*}$ \\
10 & & 2.2 & $\mathrm{NS}$ & 4.6 \\
& 15 & 2.3 & 4.8 & 5.4 \\
& 30 & 2.7 & 5.1 & 6.0 \\
Significancey & 45 & 1.9 & 5.4 & 4.4 \\
15 & 15 & 1.5 & 4.4 & 4.4 \\
& 30 & 1.2 & 4.4 & 1.1 \\
Significancey & 45 & $\mathrm{~L}^{*}$ & 1.5 & $\mathrm{Q}^{*}$ \\
\hline
\end{tabular}

${ }^{2}$ Fruit analyzed immediately upon arrival.

y $=$ linear, $\mathrm{Q}=$ quadratic.

NS,*Nonsignificant or significant at $P=0.05$.

percentage has also been reported to vary with species (Pruthi, 1963).

Sucrose content decreased quadratically at $5 \mathrm{C}$, linearly at $15 \mathrm{C}$, but increased linearly at 10C (Table 2). These results agree with those obtained by Campbell et al. (1989), who found that carambola fruit stored at 10C were of better quality than those held at 15 or $20 \mathrm{C}$. They also found that fruit kept at SC had higher levels of soluble sugars (glucose, fructose, and sucrose) than did fruit stored at higher temperatures.

Fructose and glucose content decreased quadratically with storage time at $15 \mathrm{C}$ (no change at 30 days and a dramatic drop at 45 days). Glucose content increased linearly at 5 and $10 \mathrm{C}$, but fructose content did not change at these temperatures (Table 2). Cleavage of ther work should involve temperatures between 8 and $14 \mathrm{C}$ to provide a more specific data base for commercial use.

\section{Literature Cited}

Arjona, H.E. and F.B. Matta. 1991. Postharvest quality of passion fruit as influenced by harvest time and ethylene treatment. HortScience 26:1297-1298.

Biale, Jacob B. 1975. Synthetic and degradative processes in fruit ripening, p. 5-18. In: N.F. Haard and D.K. Salunkhe (eds.). Symposium: Postharvest biology and handling of fruits and vegetables. AVI, Westport, Conn.

Campbell, C.A., D.H. Huber, and K.E. Koch. 1989. Postharvest changes in sugars, acids, and color of carambola fruit at various temperatures. HortScience 24:472-475.

McGregor, B.M. 1987. Tropical products transport handbook. U.S. Dept. Apr. Hdbk. 668.

Petersen, Roger G. 1985. Design and analysis of experiments. Marcel Dekker, New York.

Pruthi, J.S. 1963. Physiology, chemistry and technology of passion fruity, p. 203-282. In: C.O. Chichester. E.M. Mrak. and G.F. Stewart (eds.). Advanced in food research. vol. 12 Academic, New York.

sucrose may be responsible for the increase in glucose content in fruit stored at $5 \mathrm{C}$. The consumption of fructose and glucose during respiration may explain the lower fructose and glucose content of fruit stored at $15 \mathrm{C}$ relative to storage at 5 or $10 \mathrm{C}$. Fruit senescence may explain the pronounced drop in sugars at 45 days in $15 \mathrm{C}$ air.

Results from this study indicate a rapid deterioration of external appearance and/or high weight loss at 5 and $15 \mathrm{C}$ for stored yellow passion fruit. Fruit stored for 15 days at 10C had the least surface shrivel and weight loss. Also, soluble sugars were maintained at a higher level at 5 and $10 \mathrm{C}$ than at $15 \mathrm{C}$. Sugar loss was notable at $15 \mathrm{C}$. Storage at $10 \mathrm{C}$ for 15 days appears feasible for maintaining quality in yellow passion fruit. Fur-
Pruthi, J.S. and G. Lal. 1955. Some technical aspects of manufacture of passion fruit squash. Chem. Age (India) 6(2):39.

Salazar, R. and R. Torres. 1977. Almacenamiento de frutos de maracuya en bolsas de polietileno. Revista ICA-Bogota, Colombia. 12(1):1-11.

Salisbury, F.B. and C.W. Ross. 1985. Plant physiology. 3rd ed. Wadsworth, Belmont, Calif.

Sherman, M. 1985. Control of ethylene in the postharvest environment. HortScience 20:57-60.

Steel, R.G.D. and J.H. Torrie. 1980. Principles and procedures of statistics. A biometrical approach. 2nd ed. McGraw-Hill, New York.

Wills, R.B.H., T.H. Lee, D. Graham, W.B. McGlasson, and E.G. Hall. 1982. Postharvest. An introduction to the physiology and handling of fruit and vegetables. New South Wales Univ. Press, Kensington, New South Wales, Australia. 